\title{
Spatiotemporal analysis of distribution of pest and predator in corn crops
}

\author{
Marcello Neiva de Mello ${ }^{1, *}$ (1) https://orcid.org/0000-0002-0288-3252 \\ Carlos Tadeu dos Santos Dias² (iD https://orcid.org/0000-0003-1015-1761 \\ Elias Silva de Medeiros 3 (D) https://orcid.org/0000-0002-9694-4019 \\ Ivan Carlos Fernandes Martins'1D https://orcid.org/0000-0002-4405-2713 \\ Lourival Dias Campos ${ }^{1}$ (D) https://orcid.org/0000-0003-3934-1008 \\ 1. Universidade Federal Rural da Amazônia - Campus Capanema - Capanema (PA), Brazil. \\ 2. Escola Superior de Agricultura "Luiz de Queiroz" - Departamento de Ciências Exatas - Piracicaba (SP), Brazil. \\ 3. Universidade Federal da Grande Dourados - Faculdade de Ciências Exatas e Tecnológicas - Dourados (MS), Brazil. \\ *Corresponding author: neivamarcello@gmail.com
}

\begin{abstract}
Crop pests have negative impacts on yield. This paper proposes a spatiotemporal geostatistical modeling to compare data of adult Syrphidae fly count and corn leaf aphid Rhopalosiphum maidis (Fitch, 1856) colonies in corn crops. The use of a geostatistical model that allows the space-time variation makes the approach more interesting because it is a more complete model. Multiple regression was used to model the trend component for the variable response adult Syrphidae fly count and corn leaf aphid colonies, with the coordinates serving as covariates and the spatiotemporal variations around the deviation are described by a random spacetime residual field. Finally, the prediction map obtained by kriging may be a biological indicator of possible corn leaf aphid colonies in the corn crop. It was possible to verify that the occurrence of the pest provided a significant increase in adult predators and seminatural habitats may favor populations of natural enemies.
\end{abstract}

Keywords: insects; statistical methods; ecological management; Rhopalosiphum maidis; Syrphidae flies.

\section{INTRODUCTION}

Invasive species are among the most important impacts on humanity, less controlled and less reversible in the ecosystems of the world, with negative consequences, affecting its sustainability, biodiversity and economic systems (SILVA et al., 2017). In the maize crop, for example, the spike attack and stalk can lead to grain yield losses of 15 to $34 \%$ (LIMA et al., 2010).

These pests are usually controlled with the use of agrochemicals, however some pests like the corn leaf aphid Rhopalosiphum maidis (Fitch, 1856) present natural enemies that decrease their population. This can be used as a strategy in integrated pest management. BORTOLOTTO et al. (2016) report that the occurrence of populations of Syrphidae flies accompanies the aphid colonies, increasing or decreasing proportionally. This is because the flies from the Syrphidae family are adapted to lay their eggs near the corn leaf aphid colonies, since they feed on aphids in the larval phase and on pollen and nectar in the adult phase. Therefore, the presence of adult Syrphidae flies in the field may be a probable biological indicator of corn leaf aphid colony. PARK; OBRYCHI (2004) say that one way to investigate the spatiotemporal synchronization of predator and prey distributions is to generate and compare distribution maps in temporal sequences.

Tools that can describe the behavior of predators are very useful for indicating and monitoring infestations and pests. These tools include sampling and spatial analysis. Pest sampling works can be seen in FARIAS et al. (2001a). The use of spatial models is already commonly used in the literature, as can be seen in FARIAS et al. (2001b), DUARTE et al. (2015), GARCIA et al. (2017), MEHRJARDI et al. (2008), among others. A more complete approach is time-space analysis, which uses robust models to describe and predict pest incidence by studying space-time dynamics together.

Received: Jun 24, 2020. Accepted: Oct 5, 2021

Associate Editor: Silvia Galleti

Peer Review History: Double-blind Peer Review. 
Spacetime is seen as a continuous spatial arrangement combined with a temporal order of events. This union of space and time is defined in terms of its Cartesian product (CHRISTAKOS; VYAS, 1998). This extension of spatial models is a logical evolution of statistical models for mapping spatially and temporally correlated data, and facilitates the distinction between purely temporal, purely spatial or spatiotemporal variability components (KILIBARDA et al., 2014).

The objective of this paper is to model the spatiotemporal variability of corn aphid and Syrphidae family colonies in corn crops to investigate and monitor the dynamics of prey and predator infestation at different phenological stages, serving as a possible biological indicator in the field from time maps.

\section{MATERIAL AND METHODS}

\section{Study area and sampling}

The study was conducted at the Experimental Farm of Igarapé-Açu, FEIGA $\left(01^{\circ} 07^{\prime} 24^{\prime \prime} \mathrm{S}\right.$ and $\left.47^{\circ} 37^{\prime} 22^{\prime \prime} \mathrm{W}\right)$, located in the municipality of Igarapé-Açu, in the Bragantina microregion, in the mesoregion of northeastern Pará, Brazil. The site has an altitude of $39 \mathrm{~m}$ above sea level. This farm is recognized regionally for developing studies to improve animal and agricultural production techniques. The farm belongs to the Universidade Federal Rural da Amazônia, but it is also used by Embrapa and Adepará. The climate is defined as Ami, with an average annual rainfall of $2500 \mathrm{~mm}$ and an average annual temperature of $25^{\circ} \mathrm{C}$, according to the Köppen classification.

The experimental area covers $10,000 \mathrm{~m}$ (1.0 ha). A mango agroecosystem (1.7 ha), a pasture area with a predominance of Megathyrsus maximus (Jacq.) B.K. Simon and S.W.L. Jacobs ( 0.6 ha), and fragments of secondary forest are adjacent to the main site. The area was divided into 100 plots of $100 \mathrm{~m}(10 \times 10 \mathrm{~m})$. Typical planning of studies in spatial and temporal distribution must take into account spatial grid sampling in the same area and within a regular time interval (HENDERSON; SOUTHWOOD, 2016).

Prior to the corn crop, the area was cultivated with cowpea beans (Vigna unguiculata (L.) Walp), and, after harvesting, it was kept in a fallow period. On April 4, hybrid corn Priorizi M274 Morumbi was sown, with an early cycle that presents rusticity and tolerance to the main corn diseases. Both were sown with a spacing of $0.90 \mathrm{~m}$ between rows and $0.15 \mathrm{~m}$ between plants, without chemical control intervention during the cultivation period.

Sampling occurred on April 16 (12 days after sowing) to June 25, 2016, totaling 11 observations. The samples that provided the highest incidence of leafhoppers were analyzed using spatiotemporal methodology.

Ten plants were randomly chosen per plot, resulting in a total of 1,000 plants in each sampling. In order to detect the leafhoppers, a visual analysis of all parts of the plants (stem, cartridge, leaves, and ears) was performed. Subsequently, the number of insects per plot was counted. Some sharpshooters were captured with an entomological aspirator and sent to the Biodiversity Laboratory of the Universidade Federal Rural da Amazônia (UFRA), Capanema campus, to be morphotyped. Subsequently, they were sent for identification at the Entomology Department of the National Museum, Universidade Federal do Rio de Janeiro (UFRJ).

\section{Spatiotemporal models}

It is a Gaussian spatiotemporal process $\mathrm{Z}$ defined over a spatial domain $\mathrm{S}$ and a temporal domain $\mathrm{T}$ contained in the set of real numbers $R,\{Z(s, t):(s, t) \in(S \times T)\}$, where $S \subseteq R^{d}, d=2$ represented the two dimensions in space (longitude and latitude) and $\mathrm{T} \subseteq \mathrm{R}$ represented only one dimension, namely time. A statistical spatiotemporal process, observations are modeled as a partial realization of a random spacetime function (XU; SHU, 2015). The spatiotemporal variation of $\mathrm{Z}$ can be decomposed by the components of the trend $\mathrm{m}(\mathrm{s}, \mathrm{t})$ and a stochastic residual $\varepsilon(\mathrm{s}, \mathrm{t})$ (YANG et al., 2015), as can be seen in Equation 1 .

$$
Z(s, t)=m(s, t)+\varepsilon(s, t)
$$

In Equation 1 was assumed that $\mathrm{Z}$ has the moments from the first to second order. The mean component $m(s, t)=$ $\mathrm{E}[\mathrm{Z}(\mathrm{s}, \mathrm{t})]$ which is the expectation of variable $\mathrm{Z}$. Stochastic residual incorporates three components: spatial, temporal and interaction (DE IACO et al., 2015) and it is given by Equation 2.

$$
m(s, t)=\beta_{0}+\beta_{1} x_{1}+\beta_{2} x_{2}+\beta_{3} x_{3}+\beta_{4} x_{4}
$$


where $x_{1}, x_{2}, x_{3}$ and $x_{4}$ are the predictor variables of the regression model and $\beta_{0^{\prime}} \beta_{1}, \beta_{2}, \beta_{3}$ and $\beta_{4}$ are the parameters to be estimated.

For modeling, it was declared that these components are second-order stationary, mutually independent and spatially isotropic. As a binding function, it is $g[\mathrm{~m}(\mathrm{~s}, \mathrm{t})]=\log [\mathrm{m}(\mathrm{s}, \mathrm{t})]$. Due to the high numbers of zero in the response variable, the trend component was modeled by a zero-inflated Poisson (ZIP) distribution. Were considered as covariates the geographic coordinates (latitude and longitude) and a linear and quadratic temporal index. The adjusted trend model is given by Equation 3.

$$
\widehat{m}(s, t)=\hat{\beta}_{4}+\hat{\beta}_{1} x_{1}+\hat{\beta}_{2} x_{2}+\hat{\beta}_{3} x_{3}+\hat{\beta}_{4} x_{4}
$$

where the variables $x_{1}, x_{2}$ represent latitude and longitude, respectively. The variables $x_{3}$ and $x_{4}$ represent the linear and quadratic temporal effects, respectively. After the trend modeling, the next step was to model the spatiotemporal variogram on the residuals (MARTÍNEZ et al., 2017). This spatiotemporal variation not explained by the covariates is modeled by the residual component $\varepsilon(s, t)=Z(s, t)-m(s, t)$ using the spatiotemporal variogram $\left(\gamma_{s, t}\right)$ given by Equation 4 .

$$
\gamma_{s, t}\left(h_{s}, h_{t}\right)=\frac{1}{2} E\left[\varepsilon(s, t)-\varepsilon\left(s+h_{s}, t+h_{t}\right)\right]^{2}
$$

where $h s=s-s^{\prime}$ and $h_{\mathrm{t}}=t-t^{\prime}$ is for both $(s, t)$ and $\left(s^{\prime}, t^{\prime}\right)$ in the space-time domain. The next step in the analysis is to determine a theoretical model based on covariance functions that fit the data of the spatiotemporal sample variogram. To fit a theoretical model to the empirical variogram presented in Equation 4, the generalized product-sum model was used (GRÄLER et al., 2016). Variogram, half the difference in variance, is generally more useful than the covariance function because of its weaker assumptions (XU; SHU, 2015). Thus, the relationship of covariance and semivariogram in second-order stationary processes (constant mean and stationary covariance function) is given by Equation 5.

$$
\gamma\left(h_{s}, h_{t}\right)=C_{s t}(0,0)+C_{s t}\left(h_{s}, h_{t}\right)
$$

where $C_{\mathrm{st}}(0,0)$ and $C_{\mathrm{st}}\left(h_{s} h_{\mathrm{t}}\right)$ are the global sill value and the stationary covariance function, respectively. From DE CESARE et al. (2001) defined the generalized product-sum variogram as Equation 6.

$$
\gamma\left(h_{s}, h_{t}\right)=\gamma\left(h_{s}, 0\right)+\gamma\left(0, h_{t}\right)-k \gamma\left(h_{s}, 0\right) \gamma\left(0, h_{t}\right)
$$

where $\gamma_{\mathrm{st}}\left(h_{\mathrm{s}}, 0\right)$ and $\gamma_{\mathrm{st}}\left(0, h_{\mathrm{t}}\right)$ are valid spatial and temporal marginal variograms, respectively. Parameter k in Equation 5 is related to spatial and temporal sill.

\section{Spatiotemporal kriging}

For HEUVELINK et al. (2012) the spatiotemporal kriging formulas do not differ fundamentally, in a mathematical or statistical sense, from those of spatial kriging. According to KILIBARDA et al. (2014), the variogram model is crucial in spatiotemporal kriging to calculate the best unbiased linear predictor, which is given by Equation 7 .

$$
\hat{\varepsilon}\left(s_{0}, t_{0}\right)=c_{0}^{T} C_{n}^{-1} \bar{\varepsilon}
$$

where $\left(\mathrm{s}_{0}, \mathrm{t}_{0}\right)$ is the linear predictor, obtained by kriging, of the location $\left(\mathrm{s}_{0}, \mathrm{t}_{0}\right), C_{\mathrm{n}}$ is the $n \times n$ covariance matrix of the order $n \times n$ of the residuals for the $n$ points observed in spacetime, derived from the spatiotemporal variogram, $c_{0}$ is a vector of residual covariance for the observed and predicted points and $\varepsilon$ is a vector of the residuals at the $n$ observed points. KILIBARDA et al. (2014) defined the variance of the prediction error in spatiotemporal kriging as Equation 8.

$$
\begin{aligned}
& \sigma^{2}\left(s_{0}, t_{0}\right)=\operatorname{Var}\left[\varepsilon\left(s_{0}, t_{0}\right)-\hat{\varepsilon}\left(s_{0}, t_{0}\right)\right] \\
& =C(0,0)-c_{0}^{T} C_{n}^{-1} c_{0}+\left(m_{0}-M^{T} C_{n}^{-1} c_{0}\right)^{T}\left(M^{T} C_{n}^{-1} M\right)^{-1}\left(m_{0}-M^{T} C_{n}^{-1} c_{0}\right)
\end{aligned}
$$

Equation 8 is similar to spatial kriging in that the mathematical formulation is the same (HEUVELINK et al. 2012; KILIBARDA et al. 2014). $\mathrm{C}(0,0)$ is the variance for $Z, M$ is the $\mathrm{n} \times \mathrm{p}$ matrix design order of the predictor variables at the observed points and $m_{0}$ is the predictor vector at the prediction point. KILIBARDA et al. (2014) define the final predictor $\mathrm{z}\left(s_{0}, t_{0}\right)$ of the variable $\mathrm{Z}$ at location $\left(s_{0}, t_{0}\right)$ (Equation 9$)$. 


$$
\hat{z}\left(s_{0}, t_{0}\right)=\hat{m}\left(s_{0}, t_{0}\right)+\hat{\varepsilon}\left(s_{0}, t_{0}\right)
$$

where $m\left(s_{0}, t_{0}\right)$ is the estimated value for the location $\left(s_{0}, t_{0}\right)$ obtained from Equation 3 and $\left(s_{0}, t_{0}\right)$ as defined in Equation 7 . To determine the best theoretical variogram model that fits the sample variogram, the root mean square error (RMSE) was calculated, which was obtained by taking the difference in the point clouds between the sampling variogram and the theoretical variogram.

All statistical analyses were performed in software R (R CORE TEAM, 2019), using packages gstat (GRÄLER et al., 2016) and sp (BIVAND et al., 2013).

\section{RESULTS}

A gradual increase in the number of corn leaf aphid colonies can be observed over the weeks, with its apex in the last sampling (Fig. 1 a). In Figure 1 (b), maps of adult Syrphidae flies show an increase in the number of flies over time. It is also observed that the sample of June 4, 2016 has small number of flies.

(a)

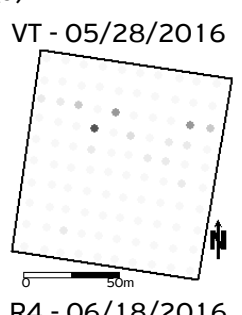

R4 - 06/18/2016

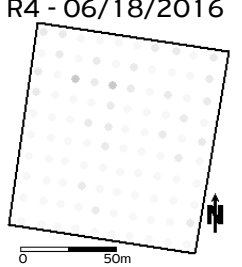

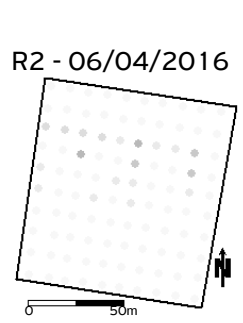

R5 - 06/25/2016

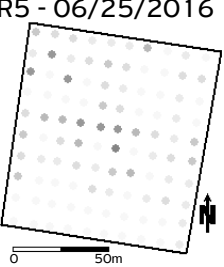

aphid colony count

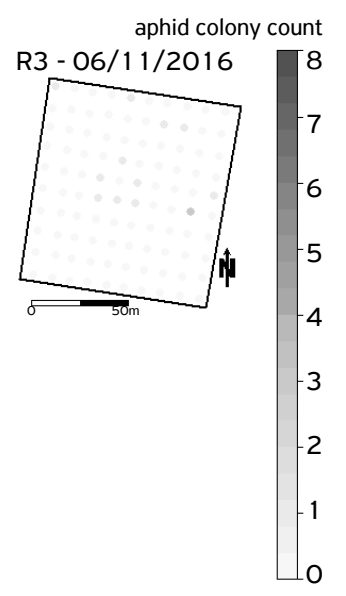

(b)

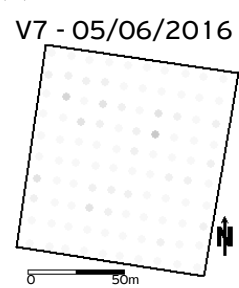

VT - 05/28/2016
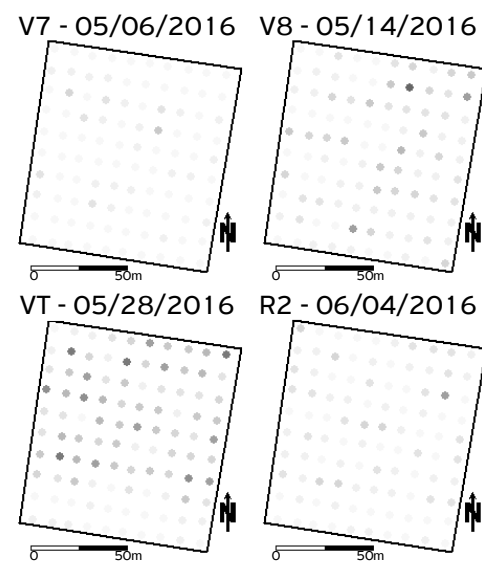

$\mathrm{R} 2$ - 06/04/2016
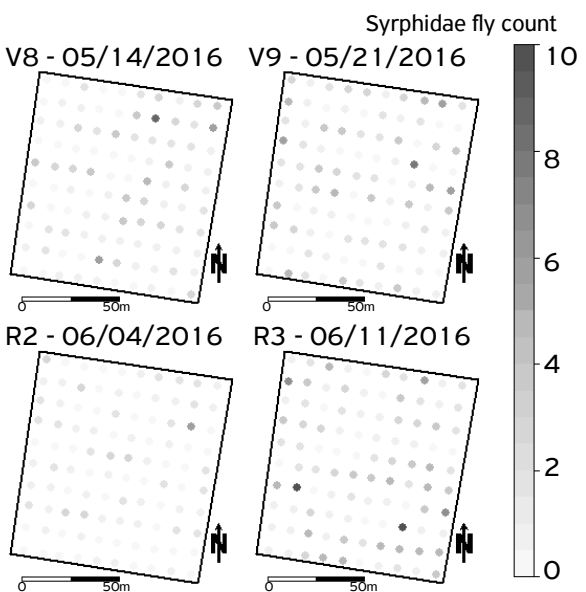

Figure 1. Spatiotemporal distribution: (a) colony corn aphid and (b) adult Syrphidae fly count in experimental crops in the northeast of Pará by weekly sampling related to the phenological stage of a hybrid corn, in 2016.

Table 1 and Figure 2 present descriptive measures and boxplots as exploratory graphs of (a) adult Syrphidae fly count and (b) corn leaf aphid colony ( $>15$ individuals) by weekly sampling intervals on a hectare located in the northeastern of the state of Pará. It is possible to verify the high variability of aphid colonies and an approximation of the average and standard deviation in adult Syrphidae flies. It is possible to observe that there are some periods with no observation of species. In the graphs, it is possible to see the great existence of zeros in both species and a possible high variability in each sample. This provides the idea that models that can handle such phenomena should be used to model the trend, such as the ZIP.

Table 1. Descriptive measures of the occurrence of aphid colonies count and adult Syrphidae flies count by weekly sampling in 1 ha located in the northeast of Pará in 2016.

\begin{tabular}{|c|c|c|c|c|c|c|c|c|c|c|c|}
\hline \multicolumn{12}{|c|}{ Aphid colonies sample dates } \\
\hline Measures & $04 / 16$ & $04 / 23$ & $04 / 30$ & $05 / 06$ & $05 / 14$ & $05 / 21$ & $05 / 28$ & $06 / 04$ & $06 / 11$ & $06 / 18$ & $06 / 25$ \\
\hline $\mathrm{m}$ & 0,00 & 0,03 & 0,00 & 0,00 & 0,00 & 0,02 & 0,35 & 0,35 & 0,14 & 0,32 & 1,37 \\
\hline $\mathrm{s}$ & 0,00 & 0,17 & 0,00 & 0,00 & 0,00 & 0,14 & 1,16 & 0,86 & 0,43 & 0,58 & 1,59 \\
\hline \multicolumn{12}{|c|}{ Syrphidae flies sample dates } \\
\hline Measures & $04 / 16$ & $04 / 23$ & $04 / 30$ & $05 / 06$ & $05 / 14$ & $05 / 21$ & $05 / 28$ & $06 / 04$ & $06 / 11$ & $06 / 18$ & $06 / 25$ \\
\hline $\mathrm{m}$ & 0,00 & 0,05 & 0,10 & 0,37 & 1,59 & 1,92 & 2,86 & 0,92 & 2,39 & 0,16 & 0,10 \\
\hline $\mathrm{s}$ & 0,00 & 0,26 & 0,36 & 0,72 & 1,63 & 1,77 & 2,22 & 1,05 & 2,08 & 0,42 & 0,39 \\
\hline
\end{tabular}

$\mathrm{m}=$ average, $\mathrm{s}=$ standard deviation. 
(a)

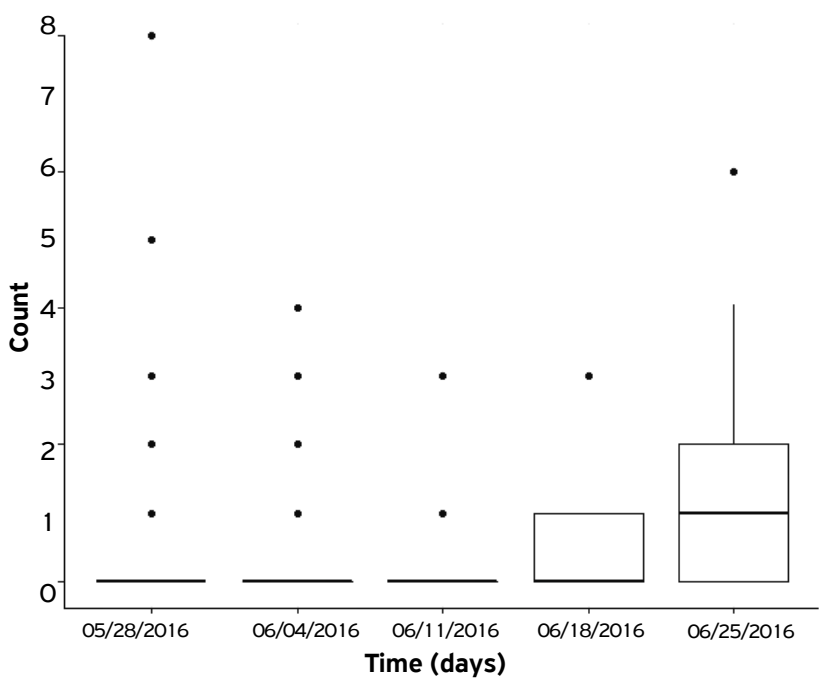

(b)

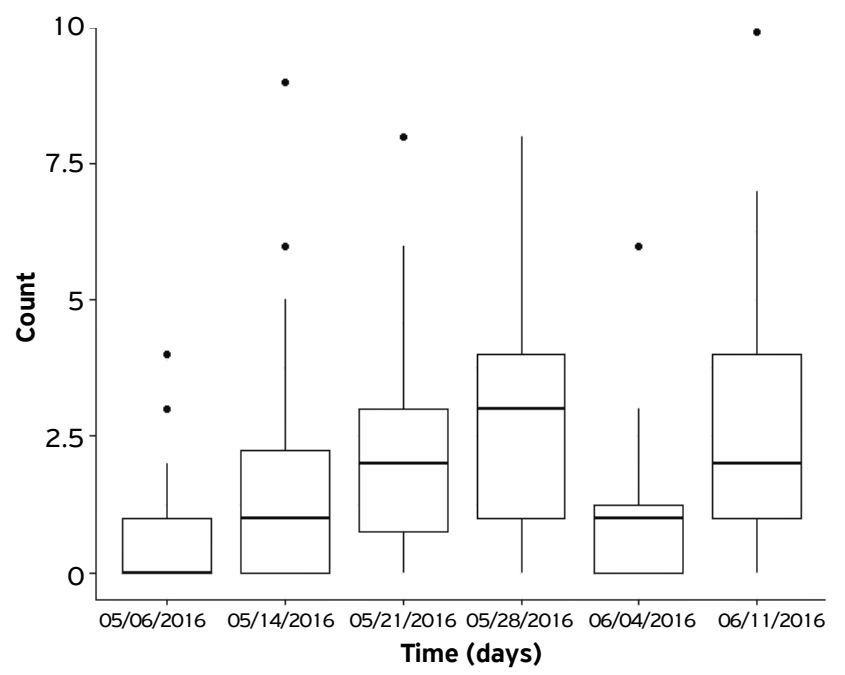

Figure 2. Boxplot: (a) colony corn aphid and (b) adult Syrphidae fly count in experimental area crops in the northeast of Pará by weekly sampling.

To model data trend the regression model was used as indicated in Equation. 3. Table 2 shows the parameter estimates, standard error, $\mathrm{t}$-statistics, and the p-value for corn leaf aphid colonies and adult Syrphidae flies. It is possible to verify that at 0.05 significance level, covariates latitude and time are associated with the counting of corn leaf aphid colony and latitude, longitude and the linear quadratic temporal effects are associated with the adult Syrphidae flies count. The residual produced by this model will be used for spatial dependence analysis.

Table 2. Estimation of the parameters of the model described in Eq. 1 for aphid colonies count and adult Syrphidae flies count by weekly sampling in one hectare located in the northeast of Pará.

\begin{tabular}{|c|c|c|c|c|}
\hline \multicolumn{5}{|c|}{ Aphid colonies } \\
\hline Variable & Estimation & Standart Deviation & t-value & p-value \\
\hline Intercept & -135800 & 29600 & -4.588 & $<0.01$ \\
\hline Latitude & 0.0138 & 0.0030 & 4.588 & $<0.01$ \\
\hline Time & 0.3227 & 0.0447 & 7.22 & $<0.01$ \\
\hline \multicolumn{5}{|c|}{ Syrphidae flies } \\
\hline Intercept & -39126.13 & 9337 & -4.190 & $<0.01$ \\
\hline Latitude & 0.0039 & 0.0009 & 4.131 & $<0.01$ \\
\hline Longitude & 0.0027 & 0.0009 & 2.905 & 0.0038 \\
\hline Time & 0.9575 & 0.1045 & 9.165 & $<0.01$ \\
\hline Time2 & -0.1079 & 0.0134 & -8.274 & $<0.01$ \\
\hline
\end{tabular}

After removing the spatiotemporal trend of the adult Syrphidae flies count and corn leaf aphid colony count, the variogram on the residual is calculated. Figure 3 shows the empirical spatiotemporal variogram model (a) and (c) and the adjusted product-sum model (b) and (d). As can be seen, the residues have a clear correlation in both space and time and the total variation of these residues is explained by spatial as well as temporal components. Note that the spatial structure becomes weaker as time differences increase and the temporal structure becomes low as spatial differences increase. The sample variogram (a) and (c) can be viewed in terms of their marginal variograms, one for space and one for time. The increasing trend in spatial and temporal dimensions in the sample variogram indicates the presence of a strong spatiotemporal correlation in both.

Table 3 presents the parameter estimates of the generalized product-sum model considering the different structures for the spatial and temporal components of adult Syrphidae flies counts and corn leaf aphid colony counts. In order to compare the models, the RMSE was used. Works such as by DE IACO et al. (2015), HU et al. (2015), JOVEIN; HOSSEINI (2017) and KILIBARDA et al. (2014) used only a single spatiotemporal correlation structure. 
(a)

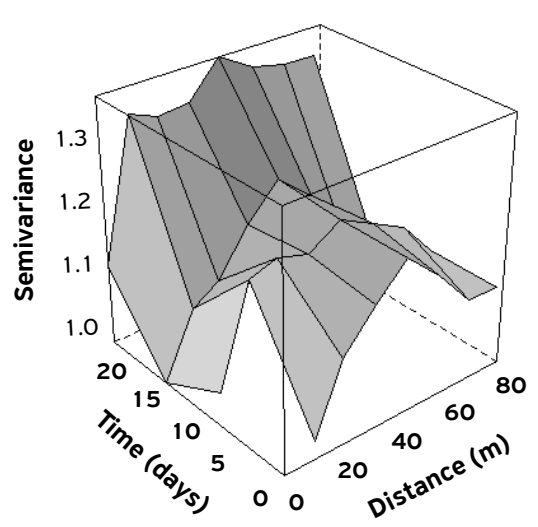

(c)

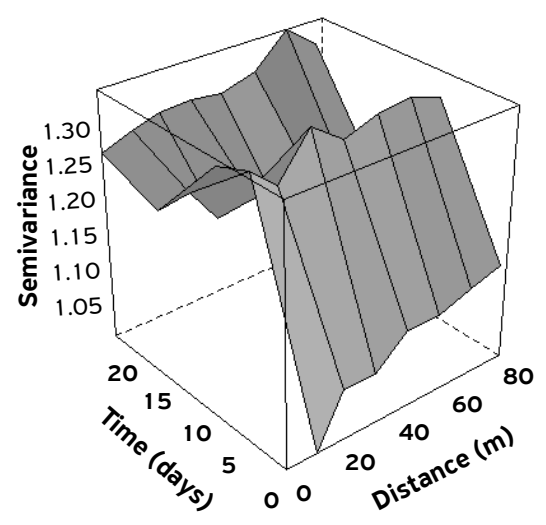

(b)
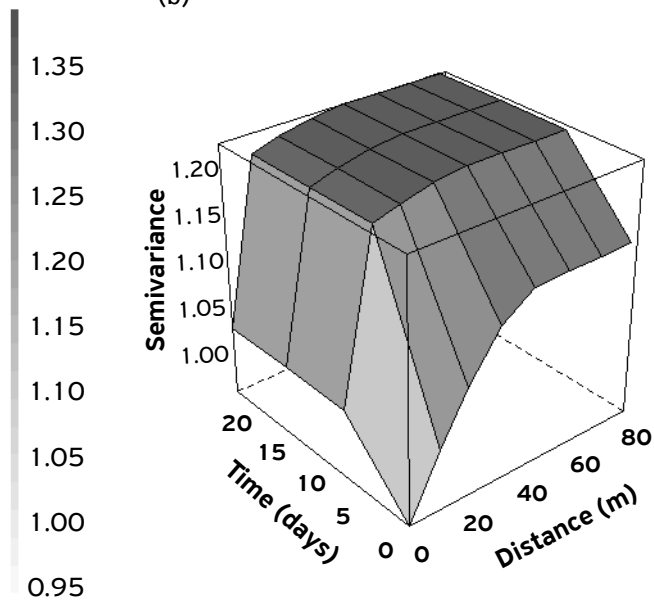

1.20

1.15

1.10

1.05

1.00

0.95

1.35
1.30
1.25
1.20
1.15
1.10
1.05
1.00
0.95

(d)

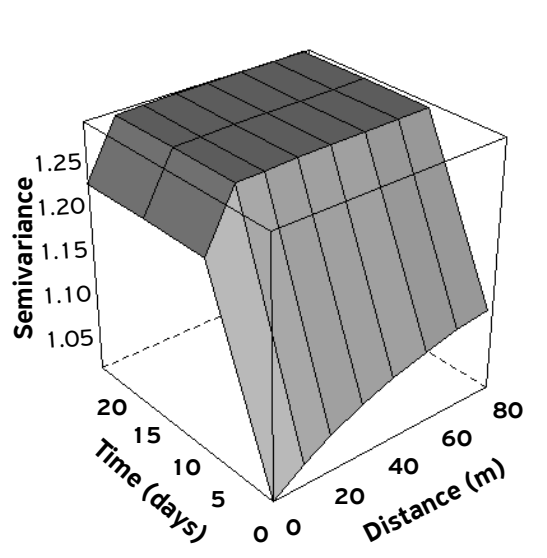

1.30
1.25
1.20
1.15
1.10
1.05
1.00

Figure 3. Spatiotemporal variogram: (a) sample for colony corn aphid; (b) product-sum model for colony corn aphid; (c) sample for adult Syrphidae fly count and (d) product-sum model for adult Syrphidae fly count in experimental area crops in the northeast of Pará.

Table 3. Estimation of the parameters of the generalized product-sum model for aphid colonies count and adult Syrphidae flies count by weekly sampling in one hectare located in the northeast of Pará.

\begin{tabular}{|c|c|c|c|c|c|c|}
\hline \multicolumn{7}{|c|}{ Aphid colonies } \\
\hline \multicolumn{2}{|c|}{ Model } & \multirow{2}{*}{$\begin{array}{c}\text { Sill } \\
0.05545781\end{array}$} & \multirow{2}{*}{$\begin{array}{c}\text { Range } \\
44.75414 \mathrm{~m}\end{array}$} & \multirow{2}{*}{$\begin{array}{c}\text { Nugget } \\
0.05545781\end{array}$} & $\mathbf{k}$ & RMSE \\
\hline Space & Exponential & & & & \multirow{2}{*}{116.670901} & \multirow{2}{*}{0.03872} \\
\hline Time & Linear & 0.241602 & 20 days & 0.12080100 & & \\
\hline \multicolumn{7}{|c|}{ Syrphidae flies } \\
\hline Space & Gaussiano & 0.069221283 & $45.65721 \mathrm{~m}$ & 0.05899567 & \multirow{2}{*}{118.540903} & \multirow{2}{*}{0.05062} \\
\hline Time & Linear & 0.1250645 & 23 days & 0.1250645 & & \\
\hline
\end{tabular}

In this paper, a broader analysis using different structures in the formation of the model was proposed. For the generalized product-sum variogram model, the exponential model for the spatial component and the linear model for the temporal component for adult Syrphidae and Gaussian and linear for corn leaf aphid were considered. The spatial range of adult Syrphidae was $46 \mathrm{~m}$, suggesting that the spatial correlation became insignificant after this threshold. On the other hand, the time interval of 23 days indicated that the temporal correlation became insignificant after this interval. For the aphid colony, the spatial amplitude was $45 \mathrm{~m}$ and the temporal interval was 20 days.

Figure 4 (a) shows an increase in corn leaf aphid colonies weekly. In the samplings, the corn leaf aphid emergence in the corn tearing stage until the last day of sampling with the tooth formation stage. In Figure 4 (b), it is possible to observe that there is a tendency of colonization that starts from the west to east. In the first sampling (May 6, 2016), there are a very small number of flies. From the second sampling (May 14, 2016) is already clear the increase of flies in the plantation. This 
is possibly due to the food supply that must be growing (corn leaf aphid colony). The sampling of May 28, 2016 presents a high rate of infestation. This phase is the corn tearing phase and, according to WEISMANN (2008), it is at this stage that the plant is most susceptible to attacks due to the greater exposure of the tassel and all the leaves. In the last two samples, it is already possible to verify a small decrease in the fly infestation. The errors were estimated and the highest values were at the edge of the area.

(a)

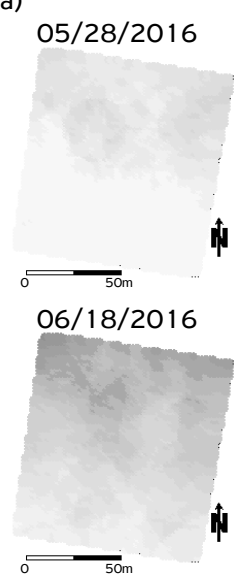

aphid colony count $06 / 11 / 2016$

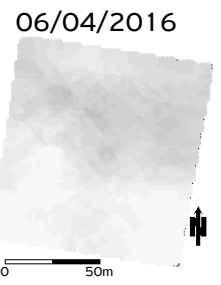

$06 / 25 / 2016$

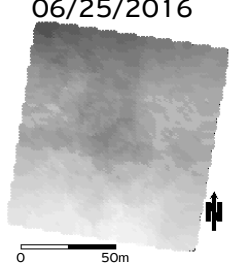

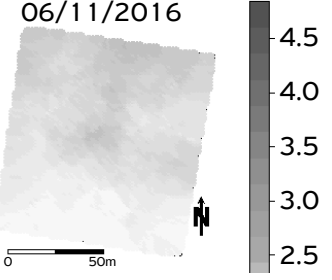

2.0

1.5

1.0

0.5

0.0 (b)

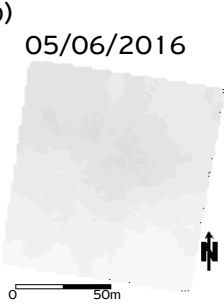

\section{$05 / 28 / 2016$}

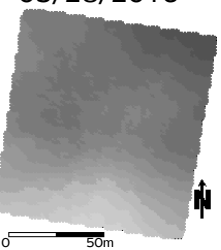

Syrphidae fly count
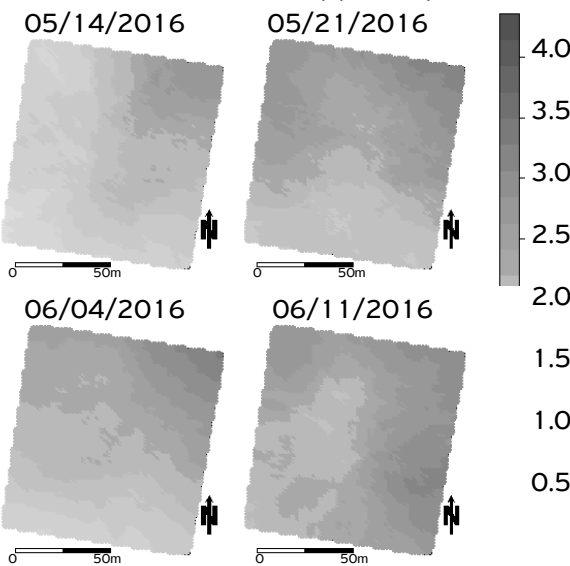

$06 / 11 / 2016$

4.0

3.5

3.0

2.5

2.0

1.5

1.0

0.5

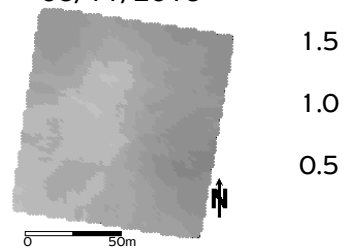

Figure 4. Prediction maps: (a) colony corn aphid and (b) adult Syrphidae fly count in experimental area crops in the northeast of Pará.

\section{DISCUSSION}

Natural aphid infestations can produce a range of population densities through different stages of plant growth and development. AL-ERYAN; EL-TABBAKH (2004) report this fact in the stages of growth V10, tearing (VT) and ripening/maturation. They also report that infestation by aphid induces yield loss of $28.14 \%$ at growth stages V10-VT, while infestation at maturity growth stages R2 to R4 caused yield loss of $16.28 \%$. CRUZ (2004) comments that infestation begins in isolated plants, mainly in the vegetative period, near the VT stage. This study showed the emergence of the aphid at the VT stage, confirming the hypothesis and higher occurrence at the reproductive stage of tooth formation (R5).

Studies such as YANG et al. (2019) showed that uncultivated habitats, such as forest plots and vegetation around dwellings or wetlands in the landscape, all had positive correlations with corn leaf aphid abundance in wheat fields because they provided sources for corn leaf aphid colonization. Besides the experiment there was an area of hose, pasture and forest fragment. These were shown to influence the colonization of corn leaf aphids and adult Syrphidae flies also in maize, as shown in the maps.

Research such as DAMICONE et al. (2007) and KLINGAUF (1987) report that wind may influence the distribution of other types of winged corn leaf aphids. The corn leaf aphids emerged near the pasture area, and wind can be a possible factor for its displacement. As corn leaf aphid colonies began to appear and grow, there was a significant increase in the number of adult Syrphidae flies in the area (May 28, 2016) that emerged from adjacent areas of forest fragments and entered the corn crop.

Probably, a forest fragment served as a shelter for the flies and provided food, since in adulthood flies feed on pollen and nectar (HOLLOWAY, 1976; MÜLLER, 1883). These seminatural habitats favor populations of natural enemies and improve their efficiency as control agents (ALIGNIER et al., 2014).

Adult flies lay their eggs near aphid colonies (WHITE et al., 1995) for the larvae to feed on them (BELLIURE; MICHAUD, 2001); so, observing adult flies is a possible indication of colonies. Although we do not have samples at the end periods of flies, it is possible to infer that the decrease in flies led to the increase in colonies or that the occurrence of this predator alone was not sufficient to decrease the aphid population. A likely natural barrier to colony control in to experiment in adjacent areas using the flowers to contribute to the fast colonization of adult flies in the presence of aphids.

Many studies, such as GASCH et al. (2015) and MEDEIROS et al. (2019) among others, show that inserting more covariates can improve the accuracy of the model. Perhaps the insertion of one or more covariates could improve the prediction in this study and better explain the influence of the pest versus predator relationship. Some advantages of using this approach are that it provides flexibility for estimating the trend component and it can consider both continuous and categorical variables, as well 
as applying different binding functions on the predictor, not requiring a Box-Cox transformation, as in HUSSAIN et al. (2010), besides modeling space and time together, not always used in applied research. Some examples of marginal analyses of these two components can be verified in papers from PELISSARI et al. (2017), ROJO; PÉREZ-BADIA (2015) and SCIARRETTA et al. (2018). A good fit can provide Gaussian errors that can be easily interpolated by keeping kriging assumptions and diagnostic tools available to evaluate the model fit (POGGIO et al., 2012). However, the use of this approach has the disadvantage that, in order to model the trend, it assumes independence and the data has known spatiotemporal dependence.

\section{CONCLUSION}

A current and flexible approach to estimating the spatiotemporal distribution of pests and natural enemies with a ZIP model and weekly temporal sampling was presented in this paper. The relationship of pests and predators may be a biological indicator in crop control to mitigate the use of agrochemicals in production crops. Seminatural habitats may favor populations of natural enemies. It was possible to verify that the occurrence of the pest provided a significant increase in adult predators. Finally, it is possible to infer that natural barriers can be used to control aphid colonies, favoring their natural enemies.

\section{AUTHORS' CONTRIBUTIONS}

Conceptualization: Mello, M.N.; Dias, C.T.S. Data curation: Martins, I.C.F.; Campos, L.D. Formal analysis: Mello, M.N.; Martins, I.C.F.; Campos, L.D. Methodology: Medeiros, E.S.; Mello, M.N.; Dias, C.T.S, Software: Medeiros, E.S; Mello, M.N. Writing - original draft: Mello, M.N.; Martins, I.C.F.; Dias, C.T.S.; Campos, L.D.; Medeiros, E.S. Writing - review \& editing: Mello, M.N.; Dias, C.T.S.

\section{AVAILABILITY OF DATA AND MATERIAL}

The datasets generated and/or analyzed during the current study are available from the corresponding author on reasonable request.

\section{FUNDING}

Coordenação de Aperfeiçoamento de Pessoal de Nível Superior

https://doi.org/10.13039/501100002322

Finance Code 001

Conselho Nacional de Desenvolvimento Científico e Tecnológico

https://doi.org/10.13039/501100003593

Grant No: 461005/2014-0

\section{CONFLICTS OF INTEREST}

All authors declare that they have no conflict of interest.

ETHICAL APPROVAL

Not applicable.

ACKNOWLEDGEMENTS

Not applicable.

\section{REFERENCES}

AL-ERYAN, M.A.S.; EL-TABBAKH, S.S. Forecasting yield of corn, Zea mays infested with corn leaf aphid, Rhopalosiphum maidis. Journal of Applied Entomology, Goettingen, v.128, n.4, p.312-315, 2004. https://doi.org/10.1111/j.1439-0418.2004.00852.x

ALIGNIER, A.; RAYMOND, L.; DECONCHAT, M.; MENOZZI, P.; MONTEIL, C.; SARTHOU, J.-P.; VIALATTE, A.; OUIN, A. The effect of semi-natural habitats on aphids and their natural enemies across spatial and temporal scales. Biological Control, Sophia Antipolis, v.77, p.76-82, 2014. https://doi.org/10.1016/j.biocontrol.2014.06.006 
BELLIURE, B.; MICHAUD, J.P. Biology and Behavior of Pseudodorus clavatus (Diptera: Syrphidae), an Important Predator of Citrus Aphids. Annals of the Entomological Society of America, Lexington, v.94, n.1, p.91-96, 2001. https://doi.org/10.1603/0013-8746(2001)094[0091:BAB $\mathrm{OPC}] 2.0 . \mathrm{CO} ; 2$

BIVAND, R.S.; PEBESMA, E.; GÓMEZ-RUBIO, V. Hello World: Introducing Spatial Data. In: Applied Spatial Data Analysis with R. New York: Springer, 2013. p.1-16. https://doi.org/10.1007/978-1-4614-7618-4_1

BORTOLOTTO, O.C.; MENEZES JÚNIOR, A.O.; HOSHINO, A.T. Abundância de inimigos naturais de pulgões do trigo em diferentes distâncias da borda da mata. Pesquisa Agropecuária Brasileira, Brasília, v.51, n.2, p.187-191, 2016. https://doi.org/10.1590/ S0100-204X2016000200011

CHRISTAKOS, G.; VYAS, V.M. A novel method for studying population health impacts of spatiotemporal ozone distribution. Social Science \& Medicine, Boston, v.47, n.8, p.1051-1066, 1998. https://doi.org/10.1016/S0277-9536(98)00171-3

CRUZ, I. Manejo de pragas da cultura do milho. In: GALVÃO, J.C.C.; MIRANDA, G.V. (eds.). Tecnologias de produção de milho. Viçosa: UFV, 2004. p.311-366.

DAMICONE, J.; EDELSON, J.V.; SHERWOOD, J.L.; MYERS, L.D.; MOTES, J.E. Effects of Border Crops and Intercrops on Control of Cucurbit Virus Diseases. Plant Disease, Saint Paul, v.91, n.5, p.509-516, 2007. https://doi.org/10.1094/PDIS-91-5-0509

DE CESARE, L.; MYERS, D.E.; POSA, D. Estimating and modeling space-time correlation structures. Statistics \& Probability Letters, East Lansing, v.51, n.1, p.9-14, 2001. https://doi.org/10.1016/S0167-7152(00)00131-0

DE IACO, S., PALMA, M.; POSA, D. Spatio-temporal geostatistical modeling for French fertility predictions. Spatial Statistics, Enschede, v.14, n.Part C, p.546-562, 2015. https://doi.org/10.1016/j.spasta.2015.10.002

DUARTE, F.; CALVO, M.V.; BORGES, A.; SCATONI, I.B. Geostatistics and Geographic Information Systems to Study the Spatial Distribution of Grapholita molesta (Busck) (Lepidoptera: Tortricidae) in Peach Fields. Neotropical Entomology, Londrina, v.44, n.4, p.319-327, 2015. https://doi.org/10.1007/s13744-015-0288-3

SILVA, L.D.; AZEVEDO, E.B.; ELIAS, R.B.; SILVA, L. Species Distribution Modeling: Comparison of Fixed and Mixed Effects Models Using INLA. International Journal of Geo-Information, Basel, v.6, n.12, p.391, 2017. https://doi.org/10.3390/ijgi6120391

FARIAS, P.R.S.; BARBOSA, J.C.; BUSOLI, A.C. Amostragem seqüencial com base na lei de Taylor para levantamento de Spodoptera frugiperda na cultura do milho. Scientia Agricola, Piracicaba, v.58, n.2, p.395-399, 2001a. https://doi.org/10.1590/S0103-90162001000200025

FARIAS, P.R.; BARBOSA, J.C.; BUSOLI, A.C. Distribuição Espacial da Lagarta-do-Cartucho, Spodoptera frugiperda (J.E. Smith) (Lepidoptera: Noctuidae), na Cultura do Milho. Neotropical Entomology, Londrina, v.30, n.4, p.681-689, 2001b. https://doi.org/10.1590/ S1519-566X2001000400025

GARCIA, A.G.; ARAUJO, M.R.; URAMOTO, K.; WALDER, J.M.M.; ZUCCHI, R.A. Geostatistics and Geographic Information System to Analyze the Spatial Distribution of the Diversity of Anastrepha Species (Diptera: Tephritidae): the Effect of Forest Fragments in an Urban Area. Environmental Entomology, Annapolis, v.46, n.6, p.1189-1194, 2017. https://doi.org/10.1093/ee/nvx145

GASCH, C.K.; HENGL, T.; GRÄLER, B.; MEYER, H.; MAGNEY, T.S.; BROWN, D.J. Spatio-temporal interpolation of soil water, temperature, and electrical conductivity in 3D + T: The Cook Agronomy Farm data set. Spatial Statistics, Enschede, v.14, n.Part A, p.70-90, 2015. https://doi.org/10.1016/j.spasta.2015.04.001

GRÄLER, B.; PEBESMA, E.; HEUVELINK, G. Spatio-Temporal Interpolation using gstat. The R Journal, v.8, n.1, p.204-218, 2016. https:// doi.org/10.32614/RJ-2016-014

HENDERSON, P.A.; SOUTHWOOD, T.R.E. Ecological Methods. Hoboken: John Wiley \& Sons, 2016.

HEUVELINK, G.B.; GRIFFITH, D.A.; HENGL, T.; MELLES, S.J. Sampling design optimization for space-time kriging. In: MATEU, J.; MÜLLER, W.G. (eds.). Spatio-temporal design: Advances in efficient data acquisition. New York: Wiley Online Library, 2012. chap.9, p.207-230. https://doi.org/10.1002/9781118441862.ch9 
HOLLOWAY, B.A. Pollen-feeding in hover-flies (Diptera: Syrphidae). New Zealand Journal of Zoology, Lincoln, v.3, n.4, p.339-350, 1976. https://doi.org/10.1080/03014223.1976.9517924

HU, Y.; LI, R.; BERGQUIST, R.; LYNN, H.; GAO, F.; WANG, Q.; ZHANG, S.; SUN, L.; ZHANG, Z.; JIANG, Q. Spatio-temporal transmission and environmental determinants of schistosomiasis japonica in Anhui Province, China. PLoS Neglected Tropical Diseases, San Francisco, v.9, n.2, p.e0003470, 2015. https://doi.org/10.1371/journal.pntd.0003470

HUSSAIN, I.; SPÖCK, G.; PILZ, J.; YU, H.-L. Spatio-temporal interpolation of precipitation during monsoon periods in Pakistan. Advances in Water Resources, Iowa, v.33, n.8, p.880-886, 2010. https://doi.org/10.1371/journal.pntd.0003470

JOVEIN, E.B.; HOSSEINI, S.M. Predicting saltwater intrusion into aquifers in vicinity of deserts using spatio-temporal kriging. Environmental Monitoring and Assessment, Orono, v.189, n.2, p.81, 2017. https://doi.org/10.1007/s10661-017-5795-8

KILIBARDA, M.; HENGL, T.; HEUVELINK, G.B.M.; GRÄLER, B.; PEBESMA, E.; TADIĆ, M.P.; BAJAT, B. Spatio-temporal interpolation of daily temperatures for global land areas at $1 \mathrm{~km}$ resolution. Journal of Geophysical Research: Atmospheres, Stony Brook, v.119, n.5, p.2294-2313, 2014. https://doi.org/10.1002/2013JD020803

KLINGAUF, F.A. Host plant finding and acceptance. In: MINKS, A.K.; HARREWIJN, P. (eds.). Aphids: their biology, natural enemies and control. Elsevier: Amsterdam, 1987. p.209-223.

LIMA, M.S.; SILVA, P.S.L.; OLIVEIRA, O.F.; SILVA, K.M.B.; FREITAS, F.C.L. Corn yield response to weed and fall armyworm controls. Planta Daninha, Viçosa, v.28, n.1, p.103-111, 2010. https://doi.org/10.1590/S0100-83582010000100013

MARTÍNEZ, W.A.; MELO, C.E.; MELO, O.O. Median Polish Kriging for space-time analysis of precipitation. Spatial Statistics, Enschede, v.19, p.1-20, 2017. https://doi.org/10.1016/j.spasta.2016.10.003

MEDEIROS, E.S.; LIMA, R.R.; OLINDA, R.A.; SANTOS, C.A.C. Modeling Spatiotemporal Rainfall Variability in Paraíba, Brazil. Water, Basel, v.11, n.9, p.1843, 2019. https://doi.org/10.3390/w11091843

MEHRJARDI, R.T.; JAHROMI, M.Z.; HEIDARI, A. Spatial distribution of groundwater quality with geostatistics (case study: YazdArdakan Plain). World Applied Sciences Journal, Giza, v.4, n.1, p.9-17, 2008. Available from: https://www.idosi.org/wasj/wasj4(1)/2.pdf. Access on: 19 Oct. 2019.

MÜLLER, H. Diptera and Thysanoptera. In: The fertilisation of flowers. London: Macmillan, 1883. 36p. https://doi.org/10.5962/bhl. title. 142366

PARK, Y.-L.; OBRYCKI, J.J. Spatio-temporal distribution of corn leaf Aphids (Homoptera: Aphididae) and lady beetles (Coleoptera: Coccinellidae) in Iowa cornfields. Biological Control, Sophia Antipolis, v.31, n.2, p.210-217, 2004. https://doi.org/10.1016/j.biocontrol.2004.06.008

PELISSARI, A.L.; FIGUEIREDO FILHO, A.; PÉLLICO NETTO, S.; EBLING, A.A.; ROVEDA, M.; SANQUETTA, C.R. Geostatistical modeling applied to spatiotemporal dynamics of successional tree species groups in a natural Mixed Tropical Forest. Ecological Indicators, Coimbra, v.78, p.1-7, 2017. https://doi.org/10.1016/j.ecolind.2017.02.044

POGGIO, L.; GIMONA, A.; BROWN, I. Spatio-temporal MODIS EVI gap filling under cloud cover: An example in Scotland. ISPRS Journal of Photogrammetry and Remote Sensing, Saint-Mandé, v.72, p.56-72, 2012. https://doi.org/10.1016/j.isprsjprs.2012.06.003

ROJO, J.; PÉREZ-BADIA, R. Spatiotemporal analysis of olive flowering using geostatistical techniques. Science of The Total Environment, Barcelona, v.505, p.860-869, 2015. https://doi.org/10.1016/j.scitotenv.2014.10.022

R CORE TEAM. R: A language and Environment for Statistical Computing. R Foundation for Statistical Computing. Vienna, Austria, 2019. Available from: https://www.R-project.org/.

SCIARRETTA, A.; TABILIO, M.R.; LAMPAZZI, E.; CECCAROLI, C.; COLACCI, M.; TREMATERRA, P. Analysis of the Mediterranean fruit fly [Ceratitis capitata (Wiedemann)] spatio-temporal distribution in relation to sex and female mating status for precision IPM. PLoS ONE, San Francisco, v.13, n.4, p.e0195097, 2018. https://doi.org/10.1371/journal.pone.0195097 
WEISMANN, M. 4 fases de desenvolvimento da cultura do milho. In: Tecnologia e Produção: Milho Safrinha e Culturas de Inverno. Maracaju: Fundação MS, 2008.

WHITE, A.J.; WRATTEN, S.D.; BERRY, N.A.; WEIGMANN, U. Habitat Manipulation to Enhance Biological Control of Brassica Pests by Hover Flies (Diptera: Syrphidae). Journal of Economic Entomology, Annapolis, v.88, n.5, p.1171-1176, 1995. https://doi.org/10.1093/ jee/88.5.1171

XU, J.; SHU, H. Spatio-temporal kriging based on the product-sum model: some computational aspects. Earth Science Informatics, Atlanta, v.8, n.3, p.639-648, 2015. https://doi.org/10.1007/s12145-014-0195-X

YANG, L.; LIU, B.; ZHANG, Q.; ZENG, Y.; PAN, Y.; LI, M.; Lu, Y. Landscape structure alters the abundance and species composition of early-season aphid populations in wheat fields. Agriculture, Ecosystems \& Environment, Nanning, v.269, p.167-173, 2019. https://doi. org/10.1016/j.agee.2018.07.028

YANG, Y.; WU, J.; CHRISTAKOS, G. Prediction of soil heavy metal distribution using Spatiotemporal Kriging with trend model. Ecological Indicators, Coimbra, v.56, p.125-133, 2015. https://doi.org/10.1016/j.ecolind.2015.03.034 